\title{
EFFECT OF THE PREDICTED CLIMATE CHANGES ON THE WATER NEEDS OF CAULIFLOWER CULTIVATED IN THE CENTRAL POLAND
}

\author{
Anna Figas ${ }^{1}$, Barbara Jagosz ${ }^{2}$, Stanisław Rolbiecki ${ }^{1}$, Roman Rolbiecki ${ }^{1}$, Wiesław Ptach $^{3}$ \\ ${ }^{1}$ University of Science and Technology in Bydgoszcz, Poland; \\ ${ }^{2}$ University of Agriculture in Krakow, Poland; ${ }^{3}$ Warsaw University of Life Sciences, Poland \\ figasanna@utp.edu.pl,bjagosz@urk.edu.pl,rolbs@utp.edu.pl, rolbr@utp.edu.pl, \\ wieslaw_ptach@sggw.pl
}

\begin{abstract}
The aim of the study was to estimate the water needs of early cultivars of cauliflower (Brassica oleracea L. var. botrytis L.). The calculations, based on the expected changes of air temperature, covered the forecasted thirty-years period, considered from 2021 to 2050. The research include the region of Bydgoszcz located in the central Poland. The forecasted mean monthly values of temperature in the region of central Poland, in the years 2021-2050, according to the climate change scenario for Poland (SRES: A1B), were used in the estimations. The water requirements of cauliflower early cultivars grown on three types of soil that diversified in terms of the water capacity (light soil, medium soil, heavy soil), were considered using two methods: Klatta's method and Press's method. The cauliflower water needs in the growing period, assumed from April to July, were calculated for each year during the considered thirty-years (2021-2050). As the reference period, the thirtyyears interval from 1981 to 2010 was applied. According to the expected changes of climate conditions, the results of study indicate that during the forecasted period (2021-2050), in the central Poland, the water requirements of cauliflower early cultivars will increase by about $6 \%$. Comparing to the reference period, considered from 1981 to 2010, the water needs of cauliflower early cultivars grown on the medium soil will increase in the forecasted years in the range from 304 to $321 \mathrm{~mm}$. On the light (sandy) soil, the water requirements of cauliflower early cultivars, calculated by the Klatta's and Press's methods, in the forecasted period will increase from 349 to $369 \mathrm{~mm}$ and from 364 to $385 \mathrm{~mm}$, respectively. While on the heavy (concise) soil, the water needs of cauliflower early cultivars in the forecasted years will increase from 258 to $273 \mathrm{~mm}$ and from 243 to $257 \mathrm{~mm}$, according to the Klatta's and Press's method, respectively. During the growing period, the highest water requirements of cauliflower early cultivars were estimated in June: $85-90 \mathrm{~mm}$ on heavy soil, $107 \mathrm{~mm}$ on medium soil and 123-129 mm on light soil. In the years 2021-2050, in July, should be expected the highest increase of cauliflower early cultivars water requirements (by about $14 \%$ ).
\end{abstract}

Keywords: Brassica oleracea L. var. botrytis L., cultivar, soil, temperature, water requirements.

\section{Introduction}

The analysis of observed climate changes, forecasted for the coming years, indicates 4a significant increase in the risk of horticultural and agricultural crop production. Special Report on Emissions Scenarios (SRES) defined four narrative storylines, labelled A1, A2, B1 and B2, describing different influences of climate change, including population growth and socio-economic development. According to the A2 scenario, at the end of the $21^{\text {st }}$ century, the global temperature will increase about $4{ }^{\circ} \mathrm{C}$. In Poland, as expected, the temperature will raise in the range of $2-4{ }^{\circ} \mathrm{C}$. At the same time, in most of the climate change scenarios for Poland, no increase in the amount of precipitation is expected [1]. Consequently, the increase in air temperature with no changes in the amount of rainfall, may lead to the excessive drying of the soil during the growing season, what will result in the use of irrigation treatments. The observed unfavourable effects of climate changes should be a contribution to the rising importance of the irrigation techniques development in Polish agriculture and horticulture production $[2 ; 3]$.

Early cultivars of cauliflower (Brassica oleracea L. var. botrytis L.) belongs to the plants with very high water requirements [4-8]. It is estimated that the water needs of cauliflower, depending on the date of cultivation, range from 250 to $340 \mathrm{~mm}$ of water during the growing season [7;9;10]. Due to the high water requirements, the plants of cauliflower should be grown on the soil with high water capacity [7]. During the cultivation of cauliflower on the light soil, satisfactory yields can only be achieved by using of the irrigation treatments [7;8;11].

The aim of present research was to estimate the water requirements of cauliflower early cultivars during the growing period, assumed from April to July, in the thirty-years interval considered from 2021 to 2050, in the central Poland (in the area of Bydgoszcz). The calculation based on the forecasted climate changes according to the scenario for Poland (SRES: A1B). The central Poland is a region, where the risk of precipitation shortage during the growing season is particularly high [12-18]. 


\section{Materials and methods}

In the research applied, according to the climate change scenario for Poland (SRES: A1B), the forecasted mean monthly values of air temperature in the central Poland (the region of Bydgoszcz) in the years 2021-2050 [19]. The water needs of cauliflower early cultivars (Brassica oleracea L. var. botrytis L.) were considered using two estimation methods, such as Klatta's method and Press's method described in the paper [10].

The plants of cauliflower were grown on the three types of soil that diversified in terms of the water capacity, including light (sandy) soil, medium soil and heavy (concise) soil [10;20;21]. The water requirements of cauliflower cultivated in the growing period, assumed from April to July, was calculated for each year of the forecasted thirty-years period, considered from 2021 to 2050 . As the reference period the thirty-years interval from 1981 to 2010 was applied.

\section{Results and discussion}

There were no differences between two applied calculation methods used to estimate the water needs of cauliflower early cultivars grown on the medium soil (Table 1). The water requirements of cauliflower early cultivars during the growing period, assumed from April to July, ranged from 269 to $345 \mathrm{~mm}$ in the reference period (1981-2010), whereas in the forecasted years, considered from 20212050, varied between 256 and $377 \mathrm{~mm}$.

Table 1

Water needs of the cauliflower early cultivars grown on the medium soils

\begin{tabular}{|c|c|c|c|c|c|c|c|}
\hline \multirow{2}{*}{ Months } & \multicolumn{2}{|c|}{ Minimum, mm } & \multicolumn{2}{c|}{ Maximum, mm } & \multicolumn{2}{c|}{ Median, mm } & $\begin{array}{c}\text { Standard } \\
\text { deviation }\end{array}$ \\
\cline { 2 - 8 } & $\begin{array}{c}\text { Klatt } \\
\text { method }\end{array}$ & $\begin{array}{c}\text { Press } \\
\text { method }\end{array}$ & $\begin{array}{c}\text { Klatt } \\
\text { method }\end{array}$ & $\begin{array}{c}\text { Press } \\
\text { method }\end{array}$ & $\begin{array}{c}\text { Klatt } \\
\text { method }\end{array}$ & $\begin{array}{c}\text { Press } \\
\text { method }\end{array}$ & $\begin{array}{c}\text { Klatt } \\
\text { method }\end{array}$ \\
\hline \multicolumn{7}{|c|}{$1981-2010$} \\
\hline April & 33 & 33 & 65 & 65 & 48 & 48 & 6.4 \\
\hline May & 51 & 51 & 90 & 90 & 71 & 71 & 7.7 \\
\hline June & 90 & 90 & 118 & 118 & 101 & 101 & 6.3 \\
\hline July & 66 & 66 & 104 & 104 & 83 & 83 & 9.4 \\
\hline April-July & 269 & 269 & 345 & 345 & 305 & 305 & 18.3 \\
\hline \multicolumn{7}{|c|}{$2021-2050$} \\
\hline April & 28 & 28 & 79 & 79 & 49 & 49 & 10.8 \\
\hline May & 48 & 48 & 101 & 101 & 70 & 70 & 13.0 \\
\hline June & 87 & 87 & 127 & 127 & 107 & 107 & 10.5 \\
\hline July & 74 & 74 & 109 & 109 & 93 & 93 & 8.5 \\
\hline April-July & 256 & 256 & 377 & 377 & 321 & 321 & 27.1 \\
\hline
\end{tabular}

In the reference period, during the growing season, the water needs of cauliflower early cultivars grown on the light soil ranged from 310 to $397 \mathrm{~mm}$, according to the estimation by the Klatta's method and from 323 to $414 \mathrm{~mm}$, when the calculation by the Press's method was performed (Table 2). In the forecasted period, the water requirements of cauliflower early cultivars were between 295 and $434 \mathrm{~mm}$ and between 308 and $452 \mathrm{~mm}$, according to the Klatta's and Press's method, respectively.

During the reference years considered from 1981 to 2010, in the period April-July, the water needs of cauliflower early cultivars grown on the heavy soil ranged between 229 and $293 \mathrm{~mm}$ using the Klatta's method and between 216 and $276 \mathrm{~mm}$ according to the Press's method (Table 3).

In the forecasted thirty-years period from 2021 to 2050, the water requirements of cauliflower early cultivars varied from 218 to $320 \mathrm{~mm}$ and from 205 to $302 \mathrm{~mm}$, calculating by the Klatta's and Press's method, respectively. 
Water needs of the cauliflower early cultivars grown on the light soil

\begin{tabular}{|c|c|c|c|c|c|c|c|}
\hline \multirow{2}{*}{ Months } & \multicolumn{2}{|c|}{ Minimum, mm } & \multicolumn{2}{c|}{ Maximum, mm } & \multicolumn{2}{c|}{ Median, mm } & $\begin{array}{c}\text { Standard } \\
\text { deviation }\end{array}$ \\
\cline { 2 - 8 } & $\begin{array}{c}\text { Klatt } \\
\text { method }\end{array}$ & $\begin{array}{c}\text { Press } \\
\text { method }\end{array}$ & $\begin{array}{c}\text { Klatt } \\
\text { method }\end{array}$ & $\begin{array}{c}\text { Press } \\
\text { method }\end{array}$ & $\begin{array}{c}\text { Klatt } \\
\text { method }\end{array}$ & $\begin{array}{c}\text { Press } \\
\text { method }\end{array}$ & $\begin{array}{c}\text { Klatt } \\
\text { method }\end{array}$ \\
\hline \multicolumn{7}{|c|}{$1981-2010$} \\
\hline April & 38 & 40 & 74 & 78 & 55 & 58 & 7.4 \\
\hline May & 59 & 61 & 104 & 109 & 82 & 85 & 8.9 \\
\hline June & 103 & 108 & 136 & 142 & 116 & 121 & 7.2 \\
\hline July & 76 & 80 & 120 & 125 & 95 & 99 & 10.9 \\
\hline April-July & 310 & 323 & 397 & 414 & 351 & 367 & 21.1 \\
\hline & \multicolumn{7}{|c|}{$2021-2050$} \\
\hline April & 32 & 34 & 91 & 95 & 57 & 59 & 12.4 \\
\hline May & 56 & 58 & 116 & 121 & 80 & 84 & 14.9 \\
\hline June & 101 & 105 & 146 & 153 & 123 & 129 & 12.1 \\
\hline July & 85 & 89 & 125 & 131 & 108 & 112 & 9.8 \\
\hline April-July & 295 & 308 & 434 & 452 & 369 & 385 & 31.1 \\
\hline
\end{tabular}

Table 3

Water needs of the cauliflower early cultivars grown on the heavy soil

\begin{tabular}{|c|c|c|c|c|c|c|c|}
\hline \multirow{2}{*}{ Months } & \multicolumn{2}{|c|}{ Minimum, mm } & \multicolumn{2}{c|}{ Maximum, mm } & \multicolumn{2}{c|}{ Median, mm } & $\begin{array}{c}\text { Standard } \\
\text { deviation }\end{array}$ \\
\cline { 2 - 8 } & $\begin{array}{c}\text { Klatt } \\
\text { method }\end{array}$ & $\begin{array}{c}\text { Press } \\
\text { method }\end{array}$ & $\begin{array}{c}\text { Klatt } \\
\text { method }\end{array}$ & $\begin{array}{c}\text { Press } \\
\text { method }\end{array}$ & $\begin{array}{c}\text { Klatt } \\
\text { method }\end{array}$ & $\begin{array}{c}\text { Press } \\
\text { method }\end{array}$ & $\begin{array}{c}\text { Klatt } \\
\text { method }\end{array}$ \\
\hline \multicolumn{7}{|c|}{$1981-2010$} \\
\hline April & 28 & 27 & 55 & 52 & 41 & 38 & 5.4 \\
\hline May & 43 & 41 & 77 & 72 & 60 & 57 & 6.7 \\
\hline June & 76 & 72 & 101 & 95 & 86 & 81 & 5.3 \\
\hline July & 56 & 53 & 89 & 84 & 70 & 66 & 8.0 \\
\hline April-July & 229 & 216 & 293 & 276 & 260 & 244 & 15.6 \\
\hline \multicolumn{7}{|c|}{$2021-2050$} \\
\hline April & 24 & 22 & 67 & 63 & 42 & 40 & 9.1 \\
\hline May & 41 & 39 & 86 & 81 & 59 & 56 & 11.0 \\
\hline June & 74 & 70 & 108 & 102 & 91 & 86 & 8.9 \\
\hline July & 63 & 59 & 93 & 87 & 79 & 75 & 7.2 \\
\hline April-July & 218 & 205 & 320 & 302 & 273 & 257 & 23.0 \\
\hline
\end{tabular}

The variation coefficient of cauliflower early cultivars water needs during the growing period, assumed from April to July, was much higher in the forecasted years 2021-2050 (8.4\%) than in the reference period, considered from 1981 to 2010 (6\%) (Table 4). The monthly variability of cauliflower early cultivars water requirements calculated in April, May and June was also higher in the forecasted years than in the reference period. On the other hand, in July, the variability of cauliflower early cultivars water needs was higher in the reference period (11.4\%) comparing the forecasted thirty-years $(9.1 \%)$. Summarizing, the highest variability of cauliflower early cultivars water requirements, both in the reference as well as forecasted period, was calculated in April and the lowest was estimated in June.

Table 4

Variation coefficient $(\%)$ of the cauliflower early cultivars water needs in the growing period

\begin{tabular}{|c|c|c|c|c|c|}
\hline \multirow{2}{*}{ Years } & \multicolumn{5}{|c|}{ Months } \\
\cline { 2 - 6 } & April & May & June & July & April-July \\
\hline $1981-2010$ & 13.0 & 10.9 & 6.3 & 11.4 & 6.0 \\
\hline $2021-2050$ & 21.9 & 18.3 & 9.8 & 9.1 & 8.4 \\
\hline
\end{tabular}


The calculations presented in the Table 5 and Table 6 indicate a clear increase in the cauliflower early cultivars water needs expected in the forecasted period, considered for thirty-years from 2021 to 2050. In the forecasted years, during the growing period, assumed from April to July, the water requirements of cauliflower early cultivars will increase in the range from 14 to $21 \mathrm{~mm}$, i.e. $6 \%$. In July, depending on the applied calculation method, was noted the highest increase of water needs (9$13 \mathrm{~mm}$, i.e. $14 \%$ ) in the forecasted period, in relation to the reference years. However, in May, in the period from 2021-2050, there was no increase in the cauliflower early cultivars water requirements, as compared to the reference period.

Table 5

Water needs $(\mathrm{mm})$ of cauliflower early cultivars in the growing period, acc. to Klatt's method

\begin{tabular}{|c|c|c|c|c|c|}
\hline \multirow{2}{*}{ Years } & \multicolumn{5}{|c|}{ Months } \\
\cline { 2 - 6 } & April & May & June & July & April-July \\
\hline \multicolumn{7}{|c|}{ Heavy soils } \\
\hline $1981-2010$ & 42 & 60 & 85 & 70 & 258 \\
\hline $2021-2050$ & 42 & 60 & 91 & 80 & 273 \\
\hline \multicolumn{7}{|c|}{ Change } \\
\hline$(2021-2050)-(1981-2010)$ & - & - & 6 & 10 & 15 \\
\hline \multicolumn{7}{|c|}{ Medium soils } \\
\hline $1981-2010$ & 49 & 71 & 101 & 83 & 304 \\
\hline $2021-2050$ & 49 & 71 & 107 & 94 & 321 \\
\hline \multicolumn{7}{|c|}{ Change } \\
\hline$(2021-2050)-(1981-2010)$ & - & - & 6 & 11 & 17 \\
\hline \multicolumn{7}{|c|}{ Light soils } \\
\hline $1981-2010$ & 57 & 82 & 116 & 95 & 349 \\
\hline $2021-2050$ & 57 & 82 & 123 & 108 & 369 \\
\hline \multicolumn{7}{|c|}{ Change } \\
\hline$(2021-2050)-(1981-2010)$ & - & - & 7 & 13 & 20 \\
\hline
\end{tabular}

Table 6

Water needs $(\mathrm{mm})$ of cauliflower early cultivars in the growing period, acc. to Press's method

\begin{tabular}{|c|c|c|c|c|c|}
\hline \multirow{2}{*}{ Years } & \multicolumn{5}{|c|}{ Months } \\
\hline & April & May & June & July & April-July \\
\hline \multicolumn{6}{|c|}{ Heavy soils } \\
\hline 1981-2010 & 39 & 57 & 80 & 66 & 243 \\
\hline $2021-2050$ & 39 & 57 & 85 & 75 & 257 \\
\hline \multicolumn{6}{|c|}{ Change } \\
\hline$(2021-2050)-(1981-2010)$ & - & - & 5 & 9 & 14 \\
\hline \multicolumn{6}{|c|}{ Medium soils } \\
\hline 1981-2010 & 49 & 71 & 101 & 83 & 304 \\
\hline $2021-2050$ & 49 & 71 & 107 & 94 & 321 \\
\hline \multicolumn{6}{|c|}{ Change } \\
\hline$(2021-2050)-(1981-2010)$ & - & - & 6 & 11 & 17 \\
\hline \multicolumn{6}{|c|}{ Light soils } \\
\hline $1981-2010$ & 59 & 85 & 121 & 99 & 364 \\
\hline $2021-2050$ & 59 & 85 & 129 & 112 & 385 \\
\hline \multicolumn{6}{|c|}{ Change } \\
\hline$(2021-2050)-(1981-2010)$ & - & - & 8 & 13 & 21 \\
\hline
\end{tabular}

In the present study, the influence of expected rising of air temperature on the water requirements of cauliflower early cultivars, was analyzed [19]. However, other meteorological elements, such as insolation, solar radiation, wind speed or air humidity, also have a significant impact on the level of water available for the plant during the growing period [1].

The forecasted climatic changes, which significantly affects the increase of water needs of the plants, including also vegetables cultivated in the field conditions, are the reason for undertaking adaptation activities. The treatments that effectively supplement the water deficiency in the plant crops 
are the irrigation techniques. Generally, the importance of the irrigation methods will grow with the increase of unfavourable climate changes [1;2;22-27]. Nowadays, in Poland, the irrigation is considered as a profitable crop treatment commonly performed in the field cultivation of vegetable plants [7;8]. The results reported by [28-32] also confirmed positive effects of the irrigation techniques on the yield of many vegetable species cultivated in the region of Bydgoszcz (central Poland).

\section{Conclusions}

1. During the forecasted period, considered from 2021 to 2050 , the water requirements of cauliflower early cultivars grown in the central Poland will increase by about $6 \%$.

2. Comparing to the reference period, assumed from 1981 to 2010 , the water needs of cauliflower grown on the medium soil will raise in the forecasted years in the range from 304 to $321 \mathrm{~mm}$.

3. On the light soil, the water needs of cauliflower early cultivars, according to the Klatta's and Press's methods, will increase from 349 to $369 \mathrm{~mm}$ and from 364 to $385 \mathrm{~mm}$, respectively.

4. The water requirements of cauliflower early cultivars grow on the heavy soil will raise from 258 to $273 \mathrm{~mm}$ and from 243 to $257 \mathrm{~mm}$, calculating by Klatta's and Press's method, respectively.

5. In the growing period, assumed from April to July, the highest water needs of cauliflower was noted in June (85-90 mm - heavy soil, $107 \mathrm{~mm}$ - medium soil, 123-129 $\mathrm{mm}$ - light soil).

6. In the years 2021-2050, in July, should be expected the highest increase of cauliflower early cultivars water requirements (by about $14 \%$ ).

\section{References}

[1] Łabędzki L., Bąk B., Liszewska M. Wpływ przewidywanej zmiany klimatu na zapotrzebowanie ziemniaka późnego na wodę. Infrastructure and Ecology of Rural Areas, vol. 2(I), 2013, pp. 155165. (In Polish)

[2] Łabędzki L. Foreseen climate changes and irrigation development in Poland. Infrastructure and Ecology of Rural Areas, vol. 3, 2009a, pp. 7-18.

[3] Łabędzki L. Expected development of irrigation in Poland in the context of climate change. Journal of Water and Land Development, vol. 13b, 2009b, pp. 17-29.

[4] Dzieżyc J. Nawadnianie roślin. Warszawa: PWN, 1974, 579 p. (In Polish)

[5] Dzieżyc J. Rolnictwo w warunkach nawadniania. Warszawa: PWN, 1988, 415 p. (In Polish)

[6] Buczak E. Potrzeby wodne roślin warzywnych. In: J. Dzieżyc (Editor). Potrzeby wodne roślin, Warszawa: PWN, 1989, pp. 159-188. (In Polish)

[7] Kaniszewski S. Nawadnianie warzyw polowych. Kraków: Plantpress, 2005, pp. 1-85. (In Polish)

[8] Kaniszewski S. Nawadnianie warzyw. In: S. Karczmarczyk \& L. Nowak (Editors). Nawadnianie roślin, Poznań: PWRiL, 2006, pp. 295-332. (In Polish)

[9] Kaniszewski S. Nawadnianie warzyw. Warszawa: PWRiL, 1987, pp. 1-108. (In Polish)

[10] Rolbiecki S., Chmura K. Optimal precipitation for field-cultivated vegetables. Infrastructure and Ecology of Rural Areas, vol. IV(3), 2014, pp. 1397-1405.

[11] Kaniszewski S., Rumpel J. Effects of irrigation, nitrogen fertilization and soil type on yield and quality of cauliflower. Journal of Vegetable Crop Production, vol. 4(1), 1998, pp. 67-75.

[12] Grabarczyk S. Efekty, potrzeby i możliwości nawodnień deszczownianych w różnych regionach kraju. Zeszyty Problemowe Postępów Nauk Rolniczych, vol. 314, 1986, pp. 49-64. (In Polish)

[13]Łabędzki L., Złonkiewicz M. Uwarunkowania i kierunki rozwoju nawodnień w regionie kujawsko-pomorskim. Zeszyty Problemowe Postępów Nauk Rolniczych, vol. 532, 2008, pp. 153162. (In Polish)

[14] Musiał E., Kamińska J. Zmienność klimatu Bydgoszczy w wieloleciu 1945-1996. Zeszyty Problemowe Postępów Nauk Rolniczych, vol. 526, 2008, pp. 113-120. (In Polish)

[15]Żarski J., Dudek S. Zmienność czasowa potrzeb nawadniania wybranych roślin w regionie Bydgoszczy. Infrastructure and Ecology of Rural Areas, vol. 3, 2009, pp. 141-149. (In Polish)

[16]Żarski J. Tendencje zmian agroklimatu rejonu Bydgoszczy w latach 1981-2010. In: M. Bieliński (Editor). Bydgoskie Kolokwium Wiedzy o Ziemi 2002-2012, Bydgoszcz: BTN, 2012, pp. 85-103. (In Polish)

[17] Łabędzki L., Bąk B. System monitorowania suszy na Kujawach. Zeszyty Problemowe Postępów Nauk Rolniczych, vol. 561, 2011, pp. 109-118. (In Polish) 
[18] Durau B., Żarski J. Niedobory opadów atmosferycznych w uprawie kapusty głowiastej białej i marchwi w rejonie Bydgoszczy w latach 1981-2010. Infrastructure and Ecology of Rural Areas, vol. 1(II), 2013, pp. 37-49. (In Polish)

[19] Bąk B., Łabędzki L. Thermal conditions in Bydgoszcz region in growing seasons 2011-2050 in view of expected climate change. Journal of Water and Land Development, vol. 23, 2014, pp. 21-29.

[20] Żakowicz S., Hewelke P. Podstawy inżynierii środowiska. Warszawa: SGGW, 2002, 140 p. (In Polish)

[21]Żakowicz S., Hewelke P., Gnatowski T. Podstawy infrastruktury technicznej w przestrzeni produkcyjnej. Warszawa: SGGW, 2009, 192 p. (In Polish)

[22] Kuchar L., Iwański S. Rainfall simulation for the prediction of crop irrigation in future climate. Infrastructure and Ecology of Rural Areas, vol. 5, 2011, pp. 7-18.

[23] Stachowski P., Markiewicz J. The need of irrigation in central Poland on the example of Kutno county. Annual Set of Environment Protection, vol. 13, 2011, pp. 1453-1472.

[24] Kuchar L., Iwański S. Rainfall evaluation for crop production until 2050-2060 and selected climate change scenarios for North Central Poland. Infrastructure and Ecology of Rural Areas, vol. 2(I), 2013, pp. 187-200.

[25]Żarski J., Dudek S., Kuśmierek-Tomaszewska R., Rolbiecki R., Rolbiecki S. Forecasting effects of plants irrigation based on selected meteorological and agricultural drought indices. Annual Set The Environment Protection, vol. 15, 2013, pp. 2185-2203.

[26] Kuchar L., Iwański S., Diakowska E., Gąsiorek E. Simulation of hydrothermal conditions for crop production purpose until 2050-2060 and selected climate change scenarios for North Central Poland. Infrastructure and Ecology of Rural Areas, vol. II(1), 2015, pp. 319-334.

[27] Kuchar L., Iwański S., Diakowska E., Gąsiorek E. Assessment of meteorological drought in 2015 for North Central part of Poland using hydrothermal coefficient (HTC) in the context of climate change. Infrastructure and Ecology of Rural Areas, vol. I(2), 2017, pp. 257-273.

[28] Rolbiecki S., Rolbiecki R., Rzekanowski Cz., Żarski J. The influence of sprinkler irrigation on yields of some vegetable crops in the region of Bydgoszcz, Poland. Acta Horticulturae, vol. 537(2), 2000, pp. 871-877.

[29] Rolbiecki R., Rolbiecki S. Effects of micro-irrigation systems on lettuce and radish production. Acta Horticulturae, vol. 729, 2007, pp. 331-335.

[30] Rolbiecki R., Rolbiecki S. Effect of surface drip irrigation on asparagus cultivars in central Poland. Acta Horticulturae, vol. 776, 2008, pp. 45-50.

[31]Rolbiecki S., Rolbiecki R., Dudek S., Kuśmierek-Tomaszewska R., Żarski J., Rzekanowski C. Requirements and effects of drip irrigation of mid-early potato on a very light soil in moderate climate. Fresenius Environmental Bulletin, vol. 24(11b), 2015, pp. 1-8.

[32] Rzekanowski Cz., Rolbiecki St., Rolbiecki R. Yields of potatoes grown on light soils under irrigation and nitrogen fertilization. Acta Horticulturae. vol. 729, 2007, pp. 347-351. 